\title{
Особливості лікування хворих з оклюзійно-стенотичними захворюваннями артерій інфраренального відділу аорти відкритим методом
}

\begin{abstract}
Мета роботи: проаналізувати ефективність хірургічного лікування оклюзійно-стенотичних уражень артерій інфраренального відділу аорти у хворих на атеросклероз шляхом диференційованого підходу до використання відкритих технологій операційних втручань. Матеріали та методи. Проаналізовано результати лікування хворих з оклюзійно-стенотичними захворюваннями артерій нижніх кінцівок внаслідок облітеруючого атеросклерозу. Із 420 пацієнтів, які були прооперовані різними методами, 98 (23,33 \%) прооперовані відкритим методом. 14 (14,29 \%) пацієнта раніше вже виконували операційні втручання; у 12 хворих діагностовано багатоповерхові ураження.

Результати досліджень та їх обговорення. Найбільше хірургічних втручань у хворих виконано у стегново-підколінному (48,98 \%) і підколінно-гомілковому (19,4 \%) сегментах із використанням шунтів і протезів. Якщо в I і II сегментах як шунтувальний матеріал майже у 100 \% використовували різні синтетичні протези, то в III, IV, V сегментах, окрім ендартеректомії (у 5 пацієнтів), використовували різні синтетичні протези у 15 (22,73 \%), автовенозне шунтування - у 46 (69,7 \%), їх комбінацію - у 12 $(18,2$ \%) пацієнтів. У 10 (10,2 \%) хворих у ранньому післяопераційному періоді виконано повторні операційні втручання (в групі порівняння у 7-12,7 \% і в 3-6,5 \% в основній групі) внаслідок ретромбозу реваскуляризованого сегмента. У 5 (9,09 \%) хворих у групі порівняння, а в основній групі в одного (2,32 \%) хворого виконали ампутації кінцівки.

Використання запропонованого діагностично-лікувального алгоритму, шкали прогнозу розвитку можливих післяопераційних ускладнень, технології лікування хворих, розроблених реконструктивно-відновних операційних втручань на артеріях з оклюзійно-стенотичними ураженнями артерій інфраренального відділу аорти, дало змогу знизити рівень післяопераційних ускладнень, кількість повторних втручань, кількість ампутацій та скоротити тривалість перебування хворих у стаціонарі.
\end{abstract}

Ключові слова: облітеруючий атеросклероз артерій нижніх кінцівок; хронічна критична ішемія нижніх кінцівок; реваскуляризація; шунтування.

Постановка проблеми і аналіз останніх досліджень та публікацій. Оклюзійно-стенотичні захворювання артерій нижніх кінцівок як наслідок облітеруючого атеросклерозу $є$ актуальною проблемою сучасної медицини, а саме судинної хірургії. Загальне поширення патологічного процесу в Європі та Північній Америці спостерігається в діапазоні від 3 до $10 \%$, із збільшенням до 1520 \% серед осіб, старших 70 років [1, 2, 7, 8, 10]. Крайнім ступенем прояву оклюзійно-стенотичних захворювань артерій $є$ хронічна критична ішемія нижніх кінцівок (XКIHK). В основі її патогенезу лежить прогресуюче ураження артеріального русла, що призводить до змін у компенсаторних механізмах (гемодинамічних і метаболічних). До подібного патофізіологічного стану призводить значний облітеруючий процес в артеріальному руслі кінцівки, який при критичній ішемії може мати як локальний, так і багатоповерховий характер ураження. Тому такі хворі обов'язково підлягають госпіталізації у зв’язку із реальним ризиком втрати ураженої кінцівки і смерті внаслідок ускладнень [3-6, 9-11].

Щороку в Європі та Північній Америці реєструють 500-1000 пацієнтів із XКIНК на 1 млн на- селення. Кількість таких пацієнтів ще вища серед хворих на цукровий діабет. За результатами найбільших мультицентрових рандомізованих досліджень, у частини пацієнтів, в яких з різних причин не вдається провести реконструктивну операцію на артеріях, через 6 місяців спостерігається втрата кінцівки в $40 \%$, та смертність до $20 \%$. Щорічна частота великих ампутацій у загальній кількості коливається від 120 до 500 на 1 млн населення. Актуальність проблеми пов'язана також з інвалідизацією пацієнтів після ампутації кінцівки, що має велике економічне і медико-соціальне значення $[1,5,6,10,11]$.

Мета роботи: проаналізувати ефективність хірургічного лікування оклюзійно-стенотичних уражень артерій інфраренального відділу аорти у хворих на атеросклероз шляхом диференційованого підходу до використання відкритих технологій операційних втручань.

Матеріали і методи. В хірургічному центрі мініінвазивної хірургії Державної наукової установи "Науково-практичний центр профілактичної та клінічної медицини” Державного управління справами, м. Київ 32014 до 2021 рр. перебували 
на лікуванні 420 пацієнтів з оклюзійно-стенотичними ураженнями інфраренального відділу аорти.

Серед 420 пацієнтів 98 (23,33 \%) прооперували відкритим методом. Саме цих хворих були розподілили на групи: група порівняння - 55 пацієнтів (56,12 \%), прооперованих з 2014 до 2017 р., яким проводили стандартний комплекс обстеження та лікування, та основна група, яка була репрезентативна першій за статтю, віком, нозологіями, склали 43 хворі (43,88 \%), прооперованих з 2018 до 2021 р. В основній групі застосовували поглиблені методи обстеження та індивідуальний вибір виконання реконструктивно-відновних операційних втручань відповідно до запропонованих вдосконалених алгоритмів лікування, в тому числі із застосуванням розробленого способу накладання анастомозу. Особливістю також було й те, що ми проводили передопераційне прогнозування факторів ризику щодо виникнення післяопераційних ретромбозів артеріального русла прооперованої кінцівки, з огляду на результати поглибленого вивчення гемодинаміки.

У групі порівняння і в основній групі чоловіків було 70 (71,42 \%) та 72 (73,47 \%) відповідно, жінок - 28 (28,58 \%) та 26 (26,53 \%) відповідно. Вік більшості хворих складав від 46 до 76 років -
72,0 \% у групі порівняння та 74,13 \% в основній групі. Ураження правої нижньої кінцівки діагностували частіше у 60 (61,22 \%) пацієнтів, ліву - у 38 (38,78 \%). Із 98 пацієнтів, раніше прооперовані в інших лікувальних закладах 14 (14,29 \%) хворих. 3 них операції прямої реваскуляризації виконали в 5 випадках, операції непрямої реваскуляризації - у 9.

Для оцінки ступеня ішемії кінцівки в роботі використано класифікацію хронічної ішемії нижніх кінцівок за Rutherford (1997 р). За категорією 4 було 32 (32,66 \%) пацієнти, за категорією 5 - 38 (38,77 \%) хворих за категорією 6 - 28 (28,57 \%) пацієнтів.

У передопераційному періоді всім пацієнтам призначали консервативну терапію, яка включала знеболювальні препарати, антитромбоцитарну терапію (препарати ацетилсаліцилової кислоти 75-100 мг або клопідогрель 75 мг), препарати цілостазолу, антибактеріальну терапію у пацієнтів категорії 5, 6 за Rutherford та препарати для корекції супутньої (кардіальної, церебральної, шлунково-кишкової, ендокринної та іншої) патології.

Співвідношення відкритих операційних втручань до інших (ендоваскулярних і гібридних) відповідно до анатомічних сегментів представлено в таблиці 1.

Таблиця 1. Розподіл відкритих операційних втручань відносно інших відповідно до атомічних сегментів

\begin{tabular}{||c|l|c|c|c||}
\hline \multirow{2}{*}{ № } & \multirow{2}{*}{ Сегменти } & \multirow{2}{*}{ Кількість пацієнтів } & \multicolumn{2}{|c||}{ Відкриті операційні втручання } \\
\cline { 4 - 5 } & & 20 & $n$ & $\%$ \\
\hline 1 & Аорто-здухвинний & 45 & 16 & 80,0 \\
\hline 2 & Здухвинно-стегновий & 166 & 48 & 24,4 \\
\hline 3 & Стегново- підколінний & 124 & 19 & 15,32 \\
\hline 4 & Підколінно-гомілковий & 65 & 4 & 6,15 \\
\hline 5 & Гомілковостопний & 420 & 98 & 23,33 \\
\hline & Всього & & & \\
\hline
\end{tabular}

За даними таблиці 1 у відсотковому співвідношенні найбільше пацієнтів прооперовано відкритим методом - в аорто-здухвинному сегменті (80 \%) і найменше в гомілковостопному (6,15 \%).

Усіх пацієнтів з оклюзійно-стенотичними ураженнями артерій інфраренального відділу аорти, прооперованих відкритим методом, розподілили за анатомічними сегментами (табл. 2).

За даними таблиці 2, найбільше операцій при оклюзійно-стенотичному ураженні артерій інфраренального відділу аорти виконано у стегно- во-підколінному (48,98 \%) і підколінно-гомілковому сегментах $(19,4 \%)$.

Окрім того, у 12 випадках діагностували поєднання оклюзійно-стенотичного ураження в різних артеріальних сегментах (багатоповерхові ураження). Так, у 8 випадках спостерігали одночасне ураження аорто-здухвинного та сегново-підколінного сегментів та в 4 випадках - поєднане ураження аорто-здухвинного та підколінно-гомілкового сегментів.

Усім пацієнтам виконували лабораторні, біохімічні та інструментальні методи обстеження, які 
Таблиця 2. Розподіл відкритих операційних втручань відповідно до сегментів

\begin{tabular}{||l|l|c|c||}
\hline \multirow{2}{*}{ № } & \multicolumn{2}{|c|}{ Сегменти } & \multicolumn{2}{|c|}{$\begin{array}{c}\text { Відкриті операційні } \\
\text { втручання }\end{array}$} \\
\cline { 3 - 4 } & \multicolumn{1}{|c||}{ 娄 } & \% \\
\hline 1 & Аорто-здухвинний & 16 & 16,32 \\
\hline 2 & $\begin{array}{l}\text { Здухвинно- } \\
\text { стегновий }\end{array}$ & 11 & 11,22 \\
\hline 3 & $\begin{array}{l}\text { Стегново- } \\
\text { підколінний }\end{array}$ & 48 & 48,98 \\
\hline 4 & $\begin{array}{l}\text { Підколінно- } \\
\text { гомілковий }\end{array}$ & 19 & 19,4 \\
\hline 5 & Гомілковостопний & 4 & 4,08 \\
\hline & Всього & 98 & 100 \\
\hline \hline
\end{tabular}

включали електрокардіографію, рентгенологічне обстеження легень, комплекс ультрасонографічних обстежень (ехокардіографію, ультразвукове дуплексне сканування черевного відділу аорти та її гілок, артерій нижніх кінцівок, артерій екстра- та інтракраніального русла, ультразвукове сканування глибокої та поверхневої венозної системи кінцівок).

В основній групі при ультразвукових методах дослідження оцінювали тип і швидкість кровотоку, індекс резистентності, регіонарний систолічний тиск, кісточково-плечовий індекс, стан стінки магістральних артерій нижніх кінцівок, характер патологічних змін у стінці артерій (наявність, локалізацію, характер атеросклеротичних бляшок). За допомогою дуплексного сканування також оцінювали прохідність і діаметр великої підшкірної вени (по можливості використовували її як автопластичний матеріал). Ультразвукове дуплексне сканування черевного відділу аорти, артерій нижніх кінцівок і зон реконструкцій виконали всім 98 $(100,0$ \%) хворим. За нашими даними, дуплексне сканування $€$ високоспецифічним методом для післяопераційного контролю зони реконструкцій.

За допомогою рентгеноконтрастної ангіографії або спіральної комп’ютерної томографії iз контрастуванням артерій визначали локалізацію, протяжність, ступінь і характер стенозу або оклюзії, проводили оцінку стану колатерального русла, прогнозували характер і об’ єм хірургічного втручання. Рентгеноконтрастну ангіографію виконали 88 (89,8 \%) хворим, а спіральну комп'ютерну томографію із контрастуванням - 10 (10,2 \%). Окрім цього, при симптомах мультифокального атеросклерозу виконували ангіографію сонних і коронарних артерій.
Вибір типу операційного втручання базувався на класифікації анатомічних уражень сегментів за TASC-II. Зокрема, показаннями були протяжність ураженого сегмента артерії більше 20 см, технічна неможливість виконання ендоваскулярного втручання та відмова пацієнта від його виконання. Таким чином, алгоритм тактики обстеження і лікування пацієнтів базувався на оцінці рівня, типу, протяжності оклюзійно-стенотичного ураження та характеру колатерального кровообігу.

Окрім цього, вибір способу реваскуляризації кінцівки визначали наявність супутньої патології та ураження інших судинних басейнів (коронарного, брахіоцефального). При цьому враховували вік пацієнта, загальний стан та тяжкість супутньої патології. Все це в сукупності значно обмежувало виконання великих за об'ємом артеріальних реконструкцій. Тому вибір об’єму реваскуляризації завжди балансує між бажанням оперуючого хірурга покращити кровопостачання кінцівки і реальною змогою хворого перенести операційне втручання та очікуваною тривалістю життя пацієнта.

Таким чином, тільки комплексний підхід визначав показання до хірургічного лікування хворих 3 оклюзійно-стенотичними ураженнями інфраренального відділу аорти, особливо з критичною ішемією нижніх кінцівок. Це дає змогу вибрати індивідуально оптимальний вид втручання і тим самим покращити результати лікування цієї тяжкої категорії пацієнтів.

Види відкритих операційних втручань відповідно до анатомічних сегментів представлено в таблиці 3.

За даними таблиці 3, найбільше хірургічних втручань у хворих виконано в стегново-підколінному і підколінно-гомілковому сегментах із використанням шунтів і протезів. 3 метою реваскуляризації нижніх кінцівок використовували різні операції. Якщо в I і II сегментах як шунтуючий матеріал майже у 100 \% використовували різні синтетичні протези, то в III-V сегментах, окрім ендартеректомії (у 5 пацієнтів), використовували різні синтетичні протези у 15 (22,73 \%), автовенозне шунтування - у 46 (69,7%), їх комбінацію в 12 (18,2 \%) пацієнтів.

Усім 98 хворим з оклюзійно-стенотичними ураженнями артерій інфраренального відділу аорти відкритим методом проведено хірургічні втручання на аорті й артеріях нижніх кінцівок. Операції виконували під загальним або спинно-мозковим знеболенням із додатковою седацією.

У більшості, у 93 (94,9 \%) пацієнтів обох груп, виконано шунтувальні операційні втручання 3 приводу оклюзійно-стенотичних уражень інфра- 


\section{З ДОСВІДУ РОБОТИ}

Таблиця 3. Види відкритих операційних втручань з їхнім розподілом за сегментам

\begin{tabular}{|c|c|c|c|}
\hline Сегменти & Вид операції & Кількість & Всього \\
\hline $\begin{array}{l}\text { Аорто- } \\
\text { здухвинний }\end{array}$ & $\begin{array}{l}\text { Протезування аорти } \\
\text { Аорто-стегнове біфуркаційне алошунтування }\end{array}$ & $\begin{array}{c}4 \\
12\end{array}$ & 16 \\
\hline $\begin{array}{l}\text { Здухвинно- } \\
\text { стегновий }\end{array}$ & $\begin{array}{l}\text { Здухвинно-стегнове алошунтування } \\
\text { Тромбінтимектомія із здухвинних артерій }\end{array}$ & $\begin{array}{l}9 \\
2\end{array}$ & 11 \\
\hline $\begin{array}{l}\text { Стегново- } \\
\text { підколінний }\end{array}$ & $\begin{array}{l}\text { Ендартеректомія із загальної стегнової артерії } \\
\text { Профундопластика автовенозною заплатою } \\
\text { Профундопластика алозаплатою } \\
\text { Стегново-стегнове автовенозне шунтування } \\
\text { Стегново-стегнове алошунтування } \\
\text { Стегново-підколінне алошунтування вище щілини колінного } \\
\text { суглоба } \\
\text { Стегново-підколінне автовенозне шунтування вище щілини } \\
\text { колінного суглоба } \\
\text { Стегново-підколінне алошунтування нижче щілини } \\
\text { колінного суглоба } \\
\text { Стегново-підколінне автовенозне шунтування нижче щілини } \\
\text { колінного суглоба }\end{array}$ & $\begin{array}{l}5 \\
6 \\
2 \\
5 \\
7 \\
8 \\
6 \\
3 \\
6\end{array}$ & 48 \\
\hline $\begin{array}{l}\text { Підколінно- } \\
\text { гомілковий }\end{array}$ & $\begin{array}{l}\text { Стегново-проксимальногомілкове автовенозне шунтування } \\
\text { Стегново-дистальногомілкове автовенозне шунтування } \\
\text { Стегново-дистальногомілкове автовенозне шунтування “in } \\
\text { situ” }\end{array}$ & $\begin{array}{c}10 \\
6 \\
3\end{array}$ & 19 \\
\hline Гомілковостопний & $\begin{array}{l}\text { Підколінно-стопне автовенозне шунтування } \\
\text { Гомілковостопне автовенозне шунтування }\end{array}$ & $\begin{array}{l}3 \\
1\end{array}$ & 4 \\
\hline Разом & & 98 & 98 \\
\hline
\end{tabular}

ренального відділу аорти і периферичних артерій і лише у 5 (5,1%) хворих - тромбінтимектомії та ендартеректоміїі.

Необхідно вказати на високу частоту операцій саме прямої реваскуляризації у пацієнтів у структурі всіх операційних втручань на артеріях інфраренального відділу аорти. Серед них майже у 70 \% хворих виконано автовенозні шунтування. Анастомози формували за власною удосконаленою методикою. Ускладенень у зоні різних видів анастомозів у ранньому післяопераційному періоді ми не спостерігали. Варто відзначити, що автовенозне шунтування $є$ методом вибору в пацієнтів із протяжними ураженнями артеріальних сегментів, особливо стосовно уражень артерій нижче щілини колінного суглоба.

Ми спостерігали 12 випадків багатоповерхового оклюзійно-стенотичного ураження (в групі порівняння -7 , в основій групі - 5). Поставало питання про можливість виконання хірургічної корекції двох судинних сегментів одночасно. Так, було успішно виконано одномоментну реконструкцію аорто-здухвинного і стегново-підколінного i/ або підколінно-гомілкового сегментів із добрими наслідками шляхом поєднання ало- та автовенозного шунтувань. Проте за результатами наших досліджень багатоповерхові оклюзивно-стенотичні ураження краще проводити ендоваскулярними i гібридними методами лікування.

10 (10,2 \%) пацієнтам у ранньому післяопераційному періоді виконано повторні операційні втручання (в групі порівняння у 7-12,7 \% і в 3-6,5 \% в основній групі), внаслідок ретромбозу реваскуляризованого сегмента, який клінічно проявлявся прогресуючою ішемією кінцівки. Серед причин ретромбозу були: сумнівні шляхи відтоку крові - у 8 пацієнтів, в одного пацієнта - технічні причини, ще в одного - встановлено інфікування алографта. Цим пацієнтам терміново проведено відновлення магістрального кровотоку шляхом тромбектомії, автовенозної пластики дистального анастомозу та автовенозного решунтування в 7 хворих групи порівняння та тромбектомії й автовенозної пластики дистального анастомозу у 3 пацієнтів основної групи. Наші дослідження показують достатньо високу ефективність і необхід- 


\section{З ДОСВІДУ РОБОТИ}

ність ранніх повторних операційних втручань у випадках післяопераційного ретромбозу.

Завдяки розробленій шкалі прогнозування ретромбозів зони реконструкцій на етапі діагностики в основній групі вдалося знизити дані ускладення на $30 \%$.

У віддаленому післяопераційному періоді в обох групах у термін до одного року було діагностовано реоклюзію у 11 (11,22 \%) пацієнтів, причому у 4 раніше оперованих у ранньому післяопераційному періоді. Частота тромбозу у віддаленому післяопераційному періоді була статистично вищою $(\mathrm{p}<0,05)$ у $8(14,54 \%)$ хворих групи порівняння, ніж у 3 (6,98 \%) основної групи. Основними причинами реоклюзій було прогресування захворювання в дистальних відділах і відсутності шляхів відтоку крові. Високий відсоток реоклюзії в групі пацієнтів, яких оперували відкритим шляхом і виконано реконструктивні операції, був представлений в основному в пацієнтів із більш високим ступенем ішемії і поганими шляхами відтоку. В 3 випадках основної групи вдалось відновити кровотік і так врятувати кінцівку. 38 хворих групи порівняння у 5 також вдалось відновити кровотік, а у 3 пацієнтів спроба не дала результату. Таким пацієнтам проведено ампутацію кінцівки на рівні стегна внаслідок прогресуючої ішемії.

За результатами дослідження частота місцевих ускладнень в обох групах у вигляді гематом, лімфореї, набряку тканин, статистично не відрізнялась і встановлена в групі порівняння в 5 (9,09 \%) пацієнтів, в основній групі - в 4 (9,3\%).

Успіхом хірургічного лікування хворих із оклюзійно-стенотичними ураженнями артерій інфраренального відділу аорти, особливо з критичною ішемією, є збереження опорної здатності кінцівки. Так, із 98 пацієнтів 6 хворим (6,12 \%) виконано первинні ампутації на нижніх кінцівках.
Невелика частота виконання первинних ампутацій характеризує адекватність передопераційної підготовки, а саме фібринолітичної терапії, результатом якої є збереження нижньої кінцівки до моменту реконструктивної операції на судинах. Разом із тим, у 5 (9,09 \%) хворих в групі порівняння, а в основній групі в одного (2,32 \%) хворого виконано ампутації кінцівки. Причиною ампутацій в ранньому післяопераційному періоді були тромбування шунтів, погані шляхи відтоку, наявність ще одного блоку враження.

Летальність в ранньому післяопераційному періоді склала в групі порівняння - 7,27 \% (померли 4 хворі), в основній групі - 4,65 \% (померли 2 хвоpi). Аналіз післяопераційної летальності показав, що в основній групі летальність була майже вдвічі нижчою. Найчастіше серед причин смерті хворих 3 оклюзійно-стенотичними ураженнями інфраренального відділу аорти і периферичних артерій на тлі атеросклеру в основному переважали гостра лівошлуночкова недостатність, гострий інфаркт міокарда, поліорганна недостатність. Превалювання кардіальних причин у загальній структурі летальності можна пояснити тим, що більшість пацієнтів мала в анамнезі IXC, післяінфарктний кардіосклероз, серцеву недостатність різного ступеня тяжкості, гіпертонічну хворобу.

Висновки. Використання запропонованого діагностично-лікувального алгоритму, шкали прогнозу розвитку можливих післяопераційних ускладнень, технології лікування хворих, розроблених реконструктивно-відновних операційних втручань на артеріях з оклюзійно-стенотичними ураженнями артерій інфраренального відділу аорти дало змогу знизити рівень післяопераційних ускладнень, повторних втручань, ампутацій та скоротити тривалість перебування хворих у стаціонарі.

\section{СПИСОК ЛІТЕРАТУРИ}

1. Горленко Ф.В.Поєднання прямих та непрямих методів реваскуляризації при хронічній ішемії нижніх кінцівок : автореф. на здобуття наук. ступеня д. мед. наук. Ужгород, 2020. - С. 40.

2. Особенности хирургической тактики при многоуровневых окклюзионно-стенотических поражениях бедренно-берцового артериальных сегментов / П. И. Никульников, А. Н. Быцай, А. В. Ратушнюк, А. В. Ликсунов // Харківська хірургічна школа. - 2013. - 3 (60). - С. 148-151.

3. A systematic review and metaanalysis of revascularization outcomes of infrainguinal chronic limb-threatening ischemia / J. Almasri, J. Adusumalli, N. Asi [et al.] // J. Vasc. Surg. - 2018. - Vol. 68. - P. 624-633.

4. Catalano M. Epidemiology of critical limb ischaemia: North Italian data / M. Catalano // Eur. J. Med. - 1993. - Vol. 2 (1).

- P. 11-14. Retrieved from: https://www.ncbi.nlm.nih.gov/ pubmed/8257998.

5. Prevalence of peripheral arterial disease results of the Heinz Nixdorf recall study / K. Kroger, A. Stang, J. Kondratieva [et al.] // Eur. J. Epidemiol. - 2006. - Vol. 21. - P. 279-285. DOI:10.1007/ s10654-006-0015-9.

6. Русин В. І. Можливості реконструктивної хірургії при ураженні судин стегново-підколінно-гомілкового сегмента / В. І. Русин, В. В. Корсак, Я. М. Попович // Клінічна хірургія. - 2008. - № 4-5. - C. 80.

7. Фуркало С. Н. Повторные вмешательства и отдаленные результаты стентирования у больных с мультифокальным атеросклерозом : материалы съезда Ассоциации сосудистых хирургов и ангиологов Украины (Донецк 6-8 окт. 2010) / 


\section{з ДОСВІДУ РОБОТИ}

С. Н. Фуркало, В. А. Колесник // Вестн. неотлож. и восстановит. медицины. - 2010. - Т. 11, № 4. - С. 544.

8. Randomized trials for endovascular treatment of infrainguinal arterial disease: systematic review and metaanalysis (Part 2: Below the knee) / S. Jens, A. P. Conijn, M. J. Koelemay [et al.] // Eur. J. Vasc. Endovasc. Surg. - 2014. - Vol. 47 (5). - P. 536-544. DOI: $10.1016 /$ j.ejvs.2014.02.012.

9. Intersociety consensus for the management of peripheral arterial disease (TASC II) / L. Norgren, W. R. Hiatt, J. A. Dormandy [et al.] // Eur. J. Vasc. Endovasc. Surg. - 2007. - Vol. 33. - S5S75. DOI: https://doi.org/ 10.1016/j.jvs.2006.12.037.

10. Черняк В. А. Результати лікування хворих з критичною ішемією нижніх кінцівок, поєднаною з мультифокальним атеросклерозом // Клінічна хірургія. - 2007, № 5-6. - С. 59.

11. Гібридні, ендоваскулярні та відкриті хірургічні втручання в лікуванні критичної ішемії нижніх кінцівок / В. В. Шапринський, Ю. М. Гупало, О. Є. Швед [та ін.] // Хірургія України. - 2017. - 4 (64). - С. 507-512.

\section{REFERENCES}

1. Horlenko, F.V. (2020). Poiednannia priamykh ta nepriamykh metodiv revaskuliaryzatsii pry khronichnii ishemii nyzhnikh kintsivok [Combination of direct and indirect methods of revascularization in lower extremities chronic ischemia]. Doctor's Extended abstract. Uzhhorod State University [in Ukrainian].

2. Nikulnikov, P., Bytsai, A., Ratushniuk, A., \& Lyksunov, A. (2013). Osobennosti hirurgicheskoy taktiki pri mnogourovnevykh oklyuzionno-stenoticheskih porazheniyah bedrenno-bertsovogo arterialnyh segmentov [Features of surgical tactics at the multilevel occlusivestenotic lesions of the femoral-tibial arterial segments]. Kharkivska Khirurhichna Shkola - Kharkiv Surgical School, 3 (60), 148-151 [in Ukrainian].

3. Almasri, J., Adusumalli, J., Asi, N., Lakis, S., Alsawas, M., Prokop, L.J. et al. (2018). A systematic review and metaanalysis of revascularization outcomes of infrainguinal chronic limb-threatening ischemia. J. Vasc. Surg., 68, 624-633.

4. Catalano, M. (1993). Epidemiology of critical limb ischaemia: North Italian data. Eur. J. Med., 2 (1), 11-14. Retrieved from: https://www.ncbi.nlm.nih.gov/pubmed/8257998.

5. Kroger, K., Stang, A., Kondratieva, J., Moebus, S., Beck, E., Schmermund, A., \& Erbel, R. (2006). Prevalence of peripheral arterial disease results of the Heinz Nixdorf recall study. Eur. J. Epidemiol., 21, 279-285. DOI:10.1007/s10654-006-0015-9.

6. Rusyn, V.I., Korsak, V.V., \& Popovych, Ya.M. (2008). Mozhlyvosti rekonstruktyvnoi khirurhii pry urazhenni sudyn stehnovo-pidkolinno-homilkovoho sehmenta [Possibilities of reconstructive surgery for vascular lesions of the femoral-popliteal-tibial segment]. Klin. Khirurhiia - Clinical Surgery, 4-5, 80 [in Ukrainian].
7. Furkalo, S., \& Kolesnyk, V. (2010). Povtornye vmeshatelstva i otdalennye rezultaty stentirovaniya u bolnykh s multyfokalnym aterosklerozom [Repeated interventions and long-term results of stenting in patients with multifocal atherosclerosis]. Vestn. neotlozh. i vosstanovyt. Medytsyny - Bulletin of Emergency and Recovery Medicine, 11 (4), 544 [in Russian].

8. Jens, S., Conijn, A.P., Koelemay, M.J., Bipat, S. \& Reekers, J.A. (2014). Randomized trials for endovascular treatment of infrainguinal arterial disease: systematic review and metaanalysis (Part 2: Below the knee). Eur. J. Vasc. Endovasc. Surg., 47 (5), 536-544. DOI: 10.1016/j.ejvs.2014.02.012.

9. Norgren, L., Hiatt, W.R., Dormandy, J.A., Nehler, M.R., Harris, K.A. \& Fowkes, F.G.R. (2007). Intersociety consensus for the management of peripheral arterial disease (TASC II). Eur. J. Vasc. Endovasc. Surg., 33, S5-S75. DOI: https://doi.org/ 10.1016/j. jvs.2006.12.037.

10. Cherniak, V. (2007). Rezultaty likuvannia khvorykh z krytychnoiu ishemiieiu nyzhnikh kintsivok, poiednanoiu z multyfokalnym aterosklerozom [The results of treatment of patients with critical lower extremity ischemia combined with multifocal atherosclerosis]. Klinichna Khirurhiia - Clinical Surgery, (5-6), 59 [in Ukrainian].

11. Shaprynskyi, V., Hupalo, Y., Shved, O., Shamrai-Sas, A., Nabolotnyi, O., \& Shapovalov, D. (2017). Hibrydni, endovaskuliarni ta vidkryti khirurhichni vtruchannia v likuvanni krytychnoi ishemii nyzhnikh kintsivok [Hybrid, endovascular and open surgery in the treatment of critical lower extremity ischemia]. Khirurhiia Ukrainy - Surgery of Ukraine, 4 (64), 507-512 [in Ukrainian].

Отримано 23.06.2021

Електронна адреса для листування: vasil.shaprynskyy@gmail.com 


\section{З ДОСВІДУ РОБОТИ}

\section{V. SHAPRINSKY}

Scientific and Practical Center for Preventive and Clinical Medicine of the State Administration, Kyiv

\section{FEATURES OF TREATMENT OF PATIENTS WITH OCCLUSIVE-STENOTIC DISEASES OF THE ARTERIES OF THE INFRARENAL AORTA BY THE OPEN METHOD}

The aim of the work: to analyze the effectiveness of surgical treatment of occlusive-stenotic lesions of the arteries of the infrarenal aorta in patients with atherosclerosis by a differentiated approach to the use of open technologies of surgical interventions.

Materials and Methods. The results of treatment of patients with occlusive-stenotic diseases of the arteries of the lower extremities as a consequence of obliterating atherosclerosis were analyzed. Among 420 patients who underwent various methods, 98 (23.33 \%) underwent open surgery. 14 (14.29\%) patients had previously undergone surgery. In 12 cases, multistage lesions were noted.

Results and Discussion. The largest number of surgical interventions in patients was performed in the femoral-popliteal (48.98 \%) and popliteal-tibial (19.4\%) segments using shunts and prostheses. If in 1 and 2 segments as a shunt material almost $100 \%$ used different synthetic prostheses then in 3,4,5 segments except endarterectomy (in 5 patients), different synthetic prostheses were used in 15 (22.73 \%), autovenous shunting in 46 (69.7\%), their combination in 12 (18.2\%) patients. In 10 (10.2\%) patients in the early postoperative period, repeated surgical interventions were performed (in the comparison group in $7-12.7 \%$ and in $3-6.5 \%$ in the main group), due to rethrombosis of the revascularized segment. in 5 (9.09\%) patients in the comparison group, and in the main group in 1 (2.32 \%) patient limb amputations were performed.

The use of the proposed diagnostic and treatment algorithm, the scale of prognosis of possible postoperative complications, treatment technology for patients, developed reconstructive surgery on arteries with occlusive-stenotic lesions of the arteries of the infrarenal aorta, reduced the number of postoperative complications, terms of stay in the hospital.

Key words: atherosclerosis of the arteries of the lower extremities; chronic critical ischemia of the lower extremities; revascularization; shunting. 